\title{
Khyal, Improvisation, and Social Change Wasanti Paranjape
}

\section{Link to Interview with Wasanti Paranjape}

For this essay, I start with the assumption that music forms an integral part of culture and is inextricably linked not only to its artistic but also to its social and political context. This article outlines the changes in North Indian classical (Hindustani) music and the resulting social changes that came about with the emergence of khyal.

\section{What is Khyal?}

Khyal is a vocal art form that has evolved over the centuries, and reached its present day form around 1900 . It is melodic and metric and allows ample opportunity for improvisation through a variety of composed templates. The emergence of khyal in the Royal Courts of India in the fourteenth century marked an enormous shift in the thinking and attitudes of North Indian classical music. It also facilitated important social changes, including a greater tolerance for intercultural and inter-religious marriage and a move towards gender equality.

By the eighteenth century, khyaliyes (the singers of khyal), hereditary musicians from established musical families (gharanas), came from two branches of North Indian classical music. One was dhruvapad, ${ }^{1}$ an older genre of Hindu orthodox music that allowed for some improvisation but mostly followed strict procedures. The other was quawwali, which originated from Indian Muslim musical culture. Both Hindu and Muslim musicians were frustrated that there was little opportunity to demonstrate their skills in developing the beauty of the raga. They wanted to create a musical art form that would give them more freedom. Though there were hundreds of states, both Hindu and Muslim, under British rule at that time, kyhal was born in the court of a Muslim ruler, Muhammad Sharqui. The final evolution of khyal is the result of both Hindu and Muslim traditions, built on the foundation of dhruvapad.

Early in the history of khyal, singers were exclusively male. The basic performing ensemble consisted of the soloist, accompaniment on harmonium, a sarangi (stringed instrument) or a violin, a drone-producing instrument called a tanpura, and the tabla. M.R. Gautam points out that the character of Khyal has evolved to include both Muslim and Hindu influences:

This version of Khyal was a compromise between the orthodox Hindu tradition and the nascent trend of liberalism in the arts, especially in music. This liberalism can be said to be the direct result of the Muslim influence. This influence definitely had a salutary effect on Indian music, especially Hindustani music, i.e. the North Indian classical music. It enriched it enormously by introducing some of the salient and beneficial features of Persian music and also by allowing musicians much scope of artistic and aesthetic expression.

Today khyal continues with this rich inheritance. The classicism of dhruvapad is combined with the more recent romanticism of quawwali, ${ }^{3}$ and the related genres of thumari ${ }^{4}$ and tappa. ${ }^{5}$ Khyal benefits from the freedom of an unprecedented scope for improvisation without the formal restrictions of dhruvapad. Bonnie C. Wade notes that foreign influence has had a salutary effect on North Indian classical music, embroidering it without eschewing its artistry and ancient heritage: "Precisely because of the diverse nature of the types of improvisation included in khyal, it is greater than any single Hindustani vocal genre. Indeed, the word khyal, from Arabic to Urdu (a Muslim language), connotes fancy or imagination, feelings and even an imaginative composition of verse as well as music" (11).

There are two types of khyal: the bara khyal is always performed in a very slow rhythm (vilambit laya); the chota khyal $^{6}$ begins with a moderate rhythm (madya laya) followed by a very fast rhythm (drut laya). The khyal composition bandish, or ciz, is of the utmost importance, as it portrays the cardinal features of the raga. The bandish has two parts: the sthai, ${ }^{7}$ in the lower tetrachord of the raga, and the antara, in the upper tetrachord. Its most important component is the mukhada, a characteristic phrase that typifies the raga and uses text taken from the first line of the 
song, and creates melodic material for most of the cadences in performances of the sthai. At times there is a secondary mukhada for the antara.

\section{Improvisation in Khyal Singing}

There are many major types of alap (improvisation usually associated with Khyal): akar (alap sung with a single vowel, such as "aa"), tans, boltans, bollant, sargam, and nom-tom, among many others.

A khyal performance begins with the alap (improvisation), whose main purpose is to show the salient features and characteristics of the raga in a gradual and systematic fashion. Another term for alap is ragalap (improvisation in a raga), and it is called rupakalapti in Sanskrit. Some artists sing the alap on a single vowel (such as "aa") or with the word nomtom, and they may choose the bolalap, where the improvisation is sung with the text of the first line or phrase of the song. The artist can sing the alap in a progression of increasing pitch, making various configurations of notes along the pitch, and this progression is called badhat. Alternatively, the artist may focus on clusters of three or four pitches.

Many artists belong to different gharanas, families who have developed a particular style of singing the alaps. There are 16 prominent gharanas in India. The Jaipur gharana uses akara, the sound of "aa," in their alap. The Agra gharana uses khataka (a style with rapid notes punctuated with sudden halts) and some zamzama embellishments (rapidly repeated motifs that almost appear to collide into one another). The Gwalier gharana uses meend (alap that incorporate sliding from one note to another) and lehak (spurious short alap sequences inserted as digressions within the song). These forms of improvisation provide a singer with multiple ways to perform the badhat.

After the alaps are sung, the sthai is rendered. At the same time a rhythmic cycle is played on the tabla, the traditional pair of drums. The mukhada is sung while returning to the sama, the first beat of this rhythmic cycle. In Sanskrit, sama means "to be in unison"; it indicates the meeting place of melody and rhythm, the communion between raga and tala. Interspersed in the sthai are more improvisations, alaps that further reveal the character and beauty of the raga. These alaps, which are metrical and sung to the text, are performed by different khyaliyes in numerous ways. Between these embellishments, the sama is sung consistently after each avartana (rhythmic cycle). The singer may also halt at each note using different gamakas (aesthetic graces), or highlight a particular swara (usually vadi swara, the melodic center of the raga) through short attractive phrases.

For the antara, improvisation is performed in the upper tetrachord. The next step is increasing the tempo of the tala (rhythm) and singing the firat-a special feature involving free vocal movement over the entire range of the raga, covering as many as three octaves. The mukhada is also sung with a flourish. At this point, the artist may start singing taans, rapid improvised passages of notes. There is a special style of rendering the taans with an innate swing that floats across the octaves; its variety and complexity depends on the virtuosity and artistic dexterity of the singer.

Bara khyal can last for an hour or two depending upon the caliber of the artist and the temperament of the audience. In some concerts, the audience is as knowledgeable as the artist and may encourage a longer performance. Chota khyal has a very similar style of improvisation, but is a short piece of music with more taans and a faster rhythm.

\section{North Indian Classical Music and Social Change}

North Indian classical music originated from Samaveda, the oldest scripture of India. Genres such as dhruvapad and prabandha (another type of prayer) created eloquent but rigid compositions. Slowly and steadily, with Muslim influence, there was a natural movement away from a strict adherence to structure and text and toward experimentation with improvisation-toward the creation of khyal. Where the songs of dhruvapad or prabandha were always related to devotion (prayers to the deities) and performed by the Brahmins (the highest caste), khyal emphasized love, emotion, and other worldly matters and featured singers from many different races, religions, and castes. Thus, the rendition of the 'Khyal' assumed a more expansive and flexible character without infringing any of the essential characteristics of North Indian classical music. 
North Indian classical music underwent tremendous change through the influence of frequent foreign invasions and conquests. ${ }^{8}$ Persian influence was the most predominant, as India was ruled by Muslims for a few hundred years. Originally, the genres of dhruvapad, dhamar, and prabandhas were sung by only the Hindu Brahmins. When Muslims occupied and ruled India, they learned these genres and some became great musicians. North Indian classical music never lost its unique characteristics (of improvisation) and identity (the ragas), but was enriched enormously by assimilating ideas from foreign music such as formation of new ragas, having more worldly themes, and less strict structure.

In India, knowledge, erudition, and art are always highly esteemed. Therefore, over time, artists from different religions, cultures, and castes are often integrated into Indian musical culture. If an artist displays sufficient skill and knowledge in performance, she is generally welcomed by other North Indian classical musicians and by the general public.

For example, my brother, who is a Brahmin, learned how to play sitar from a member of the Shudra, the lowest caste. Before the influence of khyal, this practice of learning from a lower caste was not possible. Another example is from the life of Gangubai Hangal. She was a Devadasi by birth, which means she was from a lower caste. When she was young, she went to a colony where many Brahmins used to reside. She stole some mangos from their garden, was caught, and was told never to come there again. Once she became a celebrated singer, those who banished her as a child invited her to perform and gave her lavish lunches in their homes. In this way, North Indian classical music has fostered communication and understanding between different cultures, religions, and castes.

\section{Inter-cultural and Inter-religious Marriages}

Hindu and Muslim communities have lived together for centuries in India, including in the gharanas. When India achieved its independence from Great Britain, there was great animosity and violence between these communities. Nevertheless, famous musicians like Ravi Shankar, Ali Akbar Khan, and Alla Rakha stayed together and created great music. Such close and intimate relationships between Hindu and Muslim musicians have led to many intercultural and inter-religious marriages.

Around 1600, the Muslim Emperor at the Delhi Durbar (Court), Akbar Badashaha, was very broad minded and philanthropic. He wanted the Muslim and Hindu communities to coexist peacefully, and, leading by example, chose to marry a Hindu princess from the state of Jodhpur. He allowed her to live according to her Hindu traditions in his household-quite an extraordinary gesture at the time.

Miya Tansen was a great musician at the court of Badshaha Akbar-legend is that no artist has so far surpassed his singing. He was a Hindu Brahmin who converted to Islam. He had a Hindu wife and a Muslim wife. His children from both marriages became great musicians and remained Hindus and Muslims respectively.

Abdul Karim Khan (1880-1937) was a Muslim musician gifted with a celestial voice. He could learn and absorb any tune by just hearing it once. He toured all over India giving concerts, and taught his music to Muslims and Hindus alike. He would sing bhajans (devotional songs) by sitting in the courtyards of Hindu temples, as Muslims were not allowed to go inside. In 1910, he founded Arya Sangeet Vidyalaya, a school of Indian classical music. His wife, Tara Mane, was Hindu, and all his children, also great musicians, chose to embrace Hinduism.

Other examples include the famous Hindu sitarist Ravi Shankar, who married the sister of Ali Akbar Khan, a Muslim and a celebrated artist on the sarod; and Parwin Sultana, a famous contemporary Muslim vocalist from Afghanistan whose spouse is Hindu.

Inter-cultural and inter-religious marriages between musicians are generally accepted by Indian society-where such pairings would otherwise cause great tension between communities, often only resolved by the conversion of one spouse. Through their example, these popular musical figures have helped greatly to change attitudes towards miscegenation in Indian culture. 


\section{Gender Equality}

Among Maharashtrian Hindus as in the Hindu society in general, music was not considered as an art to be taught to the ladies or girls of respectable class, in spite of the fact that they generally possess a charming musical voice in comparison to men. In social and religious functions of the ladies, they used to sing simple songs as handed down by tradition. [. . .] Again ladies never attended any concerts of Classical music, which were meant exclusively for [the] male sex. Girls of the older generation used to learn songs from their mothers or elderly ladies from the household, songs handed down from generation to generation. After, the schools for girls were started, some songs used to be taught to the girls, but these were forgotten soon after they left the schools. There was, however, no idea of teaching classical music, and the utmost limit as a career was altogether unthought-of till the beginning of the broadcast era. (Ranade 56-7)

This statement, from Music in Maharashtra, illustrates how even women from good families were denied any instruction in or exposure to North Indian classical music, not only in Maharashtra, but in all provinces of India. Now, attitudes have progressed and many women perform publicly as respected artists.

In the British Raj, there were hundreds of states, Hindu and Muslim, where master musicians would teach the women of the court how to sing and to dance. For many generations, their role revolved around their ability to please male patrons by interpreting the seductive aspects of music and literature. Over time, however, such women from Maharashtra, Konkan, and Karnataka, highly trained in khyal and other genres of North Indian classical music, sought to liberate themselves. They refused to do these traditional practices and instead gave concerts in public, achieving a new level of respect through the quality of their music. Contemporary female khyal artists who were descendants of families of traditional singers and dancers of the court include Hirabai Badodekar and Kishori Amonkar.

There was also a group of women in South India called devadasis (meaning servants of divinity), artists dedicated to the service of a temple. Devadasi families specialized in a system of music and dance known as Bharatanatyam and were taught by the nattuvanars (dance masters). They maintained these traditions from generation to generation, supported by the patronage of the Royal Courts. In northern India, foreign invasions disrupted the tradition of Bharatanatyam, replacing it with mixed forms of dancing. Subsequently, under British Rule, the Social Reform Movement in India spread propaganda that the practices of the devadasis were degrading, crude, and immoral and should be abolished. As these women lost the support of the Royal Courts, many turned to rich clients or became prostitutes, although social services did help some by finding them employment. Some of these women, such as Gangubai Hungal, still kept their music and became accomplished Khyal singers. Eventually, the British outlawed the devadasi system in 1947.

Some in India believed that the devadasi system had merit and that the British unnecessarily abolished it. Many devadasi women said that they worked only in the temples for the art of dance and music. They were independent and respected by the general public, particularly in southern India. They were their own bosses, whereas married women were expected to listen to their husbands. Currently, Bharatanatyam is being revived—not in temples, but as a popular, secular art form.

With the influence of the independence and respect gained by their predecessors, contemporary women that have excelled as khyal singers include Padma Talwalkar, Prabha Atre, Parwin Sultana, Veena Sahasrabuddhe, and Manik Rajurkar.

\section{My Own Experiences as a Musician}

North Indian classical music has a tradition called guru-shishya parampara, where the guru teaches singing to the shishya (pupil). In khyal singing, the teacher gives a pupil the bandish and then teaches the basic alap of its raga, while also demonstrating some taans. At first, it is very difficult to understand how to develop alaps in a raga.

Students must listen to how other artists perform the same material, taking care to listen in an active manner. This way, they learn not only a raga and its swara (notes), but also perceive the full scope of skillful expressions, clever and sweet combinations of swaras, and different articulations possible in that particular raga. 
A pupil must also practice the riyas of a raga every day, learning notes, character, and mood-the rasa of the ragaand experimenting with different configurations and sounds. By imitating other artists and making small variations, she learns to create her own alaps. When I was doing my riyas, two tabla players, one Hindu and one Muslim, would come to my house weekly to accompany me and practice themselves.

Improvisation is an intellectual and artistic process. It fosters a perception of music that can transcend the senses and the mind. The artist becomes submerged in the music, a state known as rasanabhuti. In the pursuit of artistic excellence, one effaces one's separate identity and gets absorbed into the experience of rasa. In improvisation, there is new beauty at every moment-each performance, each artist becomes unique. As M.R. Gautam, Head of Vocal Music at Benares Hindu University in Varansi, describes rasanabhuti,
After explaining in some detail the system of elaboration of the "Khyal," there is one significant and vital aspect of raga delineation which needs special mention. This has much to do with music of every type, in fact with all fine arts as with metaphysics. It involves in essence an ontological exploration of "Nada", as the musical vibration. This exploration has an additional quality-a quality which could be even termed spiritual, because it must appear with effortless ease and deep inner perception. In other words, musical exploration is the experience where the performer has to depersonalize himself: the manifestation of pure, complete musical sounds is possible when their creation is free from the conflict of the creator and the consciousness of creation. In Indian music especially, this is all the more important because it is by and large improvised, and therefore the total dissolution of the ego in the creative process is very essential. All spiritual approaches aim at the dissolution of the ego and the understanding of one's true self. Indian Music is an excellent and enjoyable way of achieving this. (55)

I have taught North Indian classical music privately for many years. Along with many Indian students, I have had two Canadian students: one a classical voice teacher and the other a jazz singer. Both wanted to learn the Indian art of improvisation. I also tutored my good friend Regula Qureshi, a Professor of Ethnomusicology at the University of Alberta. She is a Christian from Switzerland married to a Muslim from Pakistan. She used to play cello in the university's symphony orchestra. She wanted to play the sarangi, a string instrument from India, but as a musician trained in Western classical music, she had difficulty learning the system of North Indian classical music. She came to me for help, and there was no barrier-I accepted her as I would any other student. In time, she would accompany me while I performed. I also took two courses from her to learn more about Western music.

Later, I became Director of the Ensemble of North Indian Classical Music in the Department of Music at the University of Alberta. I had the opportunity to teach students from various cultural backgrounds: Chinese, Japanese, Canadian, Hindu, Israeli, Ukrainian, German, etc. Some were music majors, but many came from other disciplines. While directing this ensemble, I wrote two primers ${ }^{9}$ outlining the theory and songs of the ten foundational ragas of North Indian classical music - using both Indian and Western musical notation, as little educational material on this subject is currently accessible to Western musicians. I hope that I helped give the university community a more sophisticated appreciation of Hindustani classical music. I think that in the world of music there should be no barriers, and I am always open to teaching anyone irrespective of religion or culture.

\section{Conclusion}

North Indian classical music has demonstrated the potential to rise above race, religion, or caste. Women, once denied access to or participation in North Indian classical music, now perform as equals. Changing attitudes have also led to inter-cultural and inter-religious marriages, often through the musical community of the gharanas. Although the government of India has tried to eliminate caste distinctions, passing laws to that effect, much bigotry and intolerance remain. The art of music is essential, as those who exhibit knowledge, artistry, and skill are accepted whole-heartedly by both musicians and the general population-giving hope that we may one day overcome all the prejudices that divide us. 


\section{Notes}

${ }^{1}$ There are various spellings in current usage for many of the musical terms in this paragraph. An alternate spelling for druwapad is drupad.

${ }^{2}$ An alternate spelling for quawwali is qawwali.

${ }^{3}$ Quawwali originated in the Muslim culture; it is a love song, but with also the interpretation that it is the love for God.

${ }^{4}$ Alternate spelling for thumari is thumri. Thumari is a romantic love song.

${ }^{5}$ Tappa is a very short selection of rapid notes, and is extremely difficult to sing. Very few people have mastered this genre.

${ }^{6}$ An alternate spelling for chota Khyal is chhota Khyal.

${ }^{7}$ An alternate spelling for sthai is sthayi.

${ }^{8}$ Actual dates are not important for the current discussion. However, some examples are the Mughal-Rajput War waged in 1558-1578 and Tirmur's invasions in 1398.

${ }^{9}$ Naad Tarang I: The first practical Book on Hindustani (North Indian) Classical Music and Naad Tarang II on North Indian (Hindustani) Classical Music by Wasanti Paranjape and accompanying compact discs are forthcoming publications of Padmagandh, Pune, India. In the interim, copies of the books and CDs may be purchased from the author: E-mail bhala.jape@gmail.com, Mailing address 58 Hands Drive, Guelph, ON N1G 3H3, telephone 519-2650405.

\section{Acknowledgements}

I would like to thank Maureen Durnin, Asha (Sadanand) Paranjape, Karl Coulthard and Ajay Heble for extensive editorial assistance. All views expressed in the article are mine.

\section{Works Cited}

Anonymous. "Bharata Natyam." Wikipedia. Web. 2 Dec. 2012.

Gautam, M.R. The Musical Heritage of India. New Delhi: Abhinav Publications, 1980. Print.

Ranade G.M. Music of Maharashtra. New Delhi: Maharashtra Information Centre, 1967. Print.

Wade, Bonnie C. Khyal: Creativity within North India's Classical Music Tradition. Cambridge: Cambridge UP, 1984. Print. 